"This is the peer reviewed version of the following article: First Late Ordovician conodont fauna in the Betic Cordillera (South Spain): a palaeobiogeographical contribution, which has been published in final form at doi: https://doi.org/10.1111/j.1365-3121.2010.00954. This article may be used for noncommercial purposes in accordance with Wiley Terms and Conditions for Use of SelfArchived Versions."

\title{
First Late Ordovician conodont fauna in the Betic Cordillera (South Spain): a palaeobiogeographical contribution
}

\author{
R. Rodríguez-Cañero, ${ }^{1}$ A. Martín-Algarra, ${ }^{1,2}$ G. N. Sarmiento ${ }^{3}$ and P. Navas-Parejo ${ }^{1}$ \\ ${ }^{1}$ Departamento de Estratigrafía y Paleontología, Universidad de Granada, 18071 Granada, Spain; ${ }^{2}$ Instituto Andaluz de Ciencias de la Tierra \\ (CSIC-UGR), 18071 Granada, Spain; ${ }^{3}$ Departamento de Paleontología e Instituto de Geología Econámica (CSIC-UCM), Facultad de CC. \\ Geológicas, 28040 Madrid, Spain
}

\begin{abstract}
ABST RACT
The youngest Ordovician conodont fauna in SW Europe has been found in the Malaguide Complex of the Betic Cordillera, SE Spain. It is also the first Ordovician conodont fauna in the Western Mediterranean Alpine Orogen. The conodont association, attributed to the Hirnantian (upper part of the Amorphognathus ordovicicus Biozone), is characterized by the predominance of Walliserodus amplissimus and Scabbardella alt-ipes and by the absence of Sagittodontina and Istorinus, typical of the Mediterranean Province. This fauna differs markedly from those of the same biozone recorded in the Spanish Variscan Orogen of the Iberian Massif, which are attributed to the Katian. The Malaguide fauna shows, however, striking similarity to faunas of the Carnic Alps and some resemblance to those of the Pyrenees, Northern England and North Wales. These features suggest that Palaeozoic terranes of the Betic Cordillera were located far to the east of their present location and displaced westward during the Alpine Orogeny.
\end{abstract}

\section{Introduction}

In southernmost Spain, Palaeozoic rocks, usually metamorphic, are exposed only in the Internal Domain of the Betic Cordillera that is the westernmost European Alpine Belt (Herbig, 1984; Martín-Algarra, 1987; Martín-Algarra et al., 2004). None- theless, thick terrigenousclastic sedi- mentary Palaeozoic successions are present in the Malaguide Complex, where Llandovery to Bashkirian deposits have been dated mainly by conodonts. Conodonts are, consequently, essential tools for improving the poorly known Palaeozoic stratigraphy, and understanding the very complicated Alpine and pre-Alpine tectonic structure and geological history of this belt.

Silurian, Devonian and Carboniferous conodonts were reported by Kockel (1959) and Kockel and Stoppel (1962) in the western outcrops of the Malaguide Complex and, a few years later, in the eastern regions (van den Boogaard, 1965). Herbig (1984, 1985) identified several Middle and Upper Devonian and Carboniferous biozones; Rodríguez-Car̃ero (1993a) demonstrated the presence of many conodont biozones of the Middle and Upper Silurian, the Lower, Middle and Upper Devonian, and the Lower Carboniferous (Table 1). Most of these conodonts were obtained from: (i) tectonically isolated and scattered Silurian and Devonian car- bonate outcrops with stratigraphic successions that vary from a few metres to several tens of metres in thickness (Kockel, 1959; Kockel and Stoppel, 1962; Herbig, 1984, 1985; Rodríguez-Cañæro, 1993a,b); (ii) Low- er Carboniferous thin siliceous and carbonate deposits intercalated between unfossiliferous turbiditic slates and greywackes (Herbig, 1983; Rodríguez-Cañero and Guerra-Merchá n, 1996; O'Dogherty et al., 2000; NavasParejo et al., 2008); and (iii) centimetre- to few metre-sized Devonian-Carboniferous carbonate clasts included within Carboniferous conglomerates (Buchroithner et al., 1980; Herbig, 1984).

The existence of Ordovician deposits in the Malaguide Complex of the Betic Cordillera was suspected (Martín-Algarra et al., 2004) but, until now, not biostratigraphically demonstrated. The present study reveals the existence of Upper Ordovician strata, which have been dated by conodonts of the Amorphognathus ordovicicus Biozone for the first time in the Betic Cordillera. In spite of its local character, this discovery is rele- vant because it represents the firstsolid evidence of the presence of ordovician rocks in the Palaeozoic successions of the Western Mediterranean Alpine Chains that extend from southern Italy to Gibraltar. Consequently, this allows correlation with the well-known succession in the Alps and in other North-Gondwanic areas, and with the new standard chronostratigraphic scale (Bergströ m et al., 2009).

\section{Geological setting}

As is usual for mountain belts in the Western Mediterranean Alpine Orogenic System, the Betic Cordillera is divided into tectonic units belonging to the External, Flysch and Internal Domains (Durand-Delga and Fontboté , 1980; Vera and Martí nAlgarra, 2004). As a consequence of the post- Palaeozoic Pangaea breakoff, these domains constituted, from mid- Jurassic time, the northern (External) and southern (Internal) continental margins of a narrow, deep marine (Flysch) basin that connected the western Tethyan and central Atlantic oceans. Cretaceous to Miocene subduction and metamorphism followed by continental collision transformed these former margins and basin, and their basements, in the Alpine stack of thrust nappes that constitute the Betic Cordillera today.

Palaeozoic terranes are practically absent in the External and Flysch 
Table 1 Conodont biozones in the Malaguide Complex after Rodríguez-Cañero (1993a). Numbers correspond to samples.

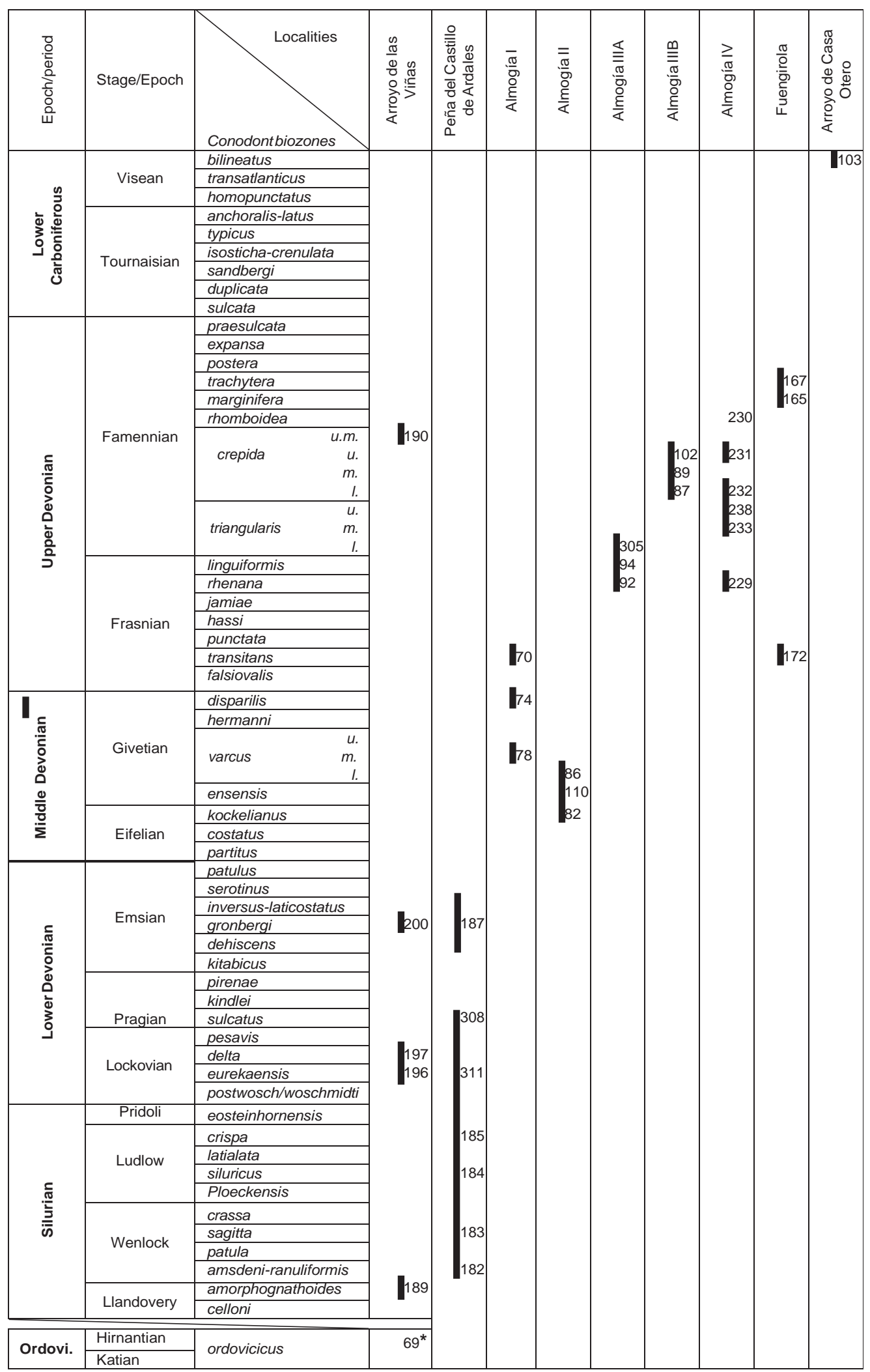

*This paper. 


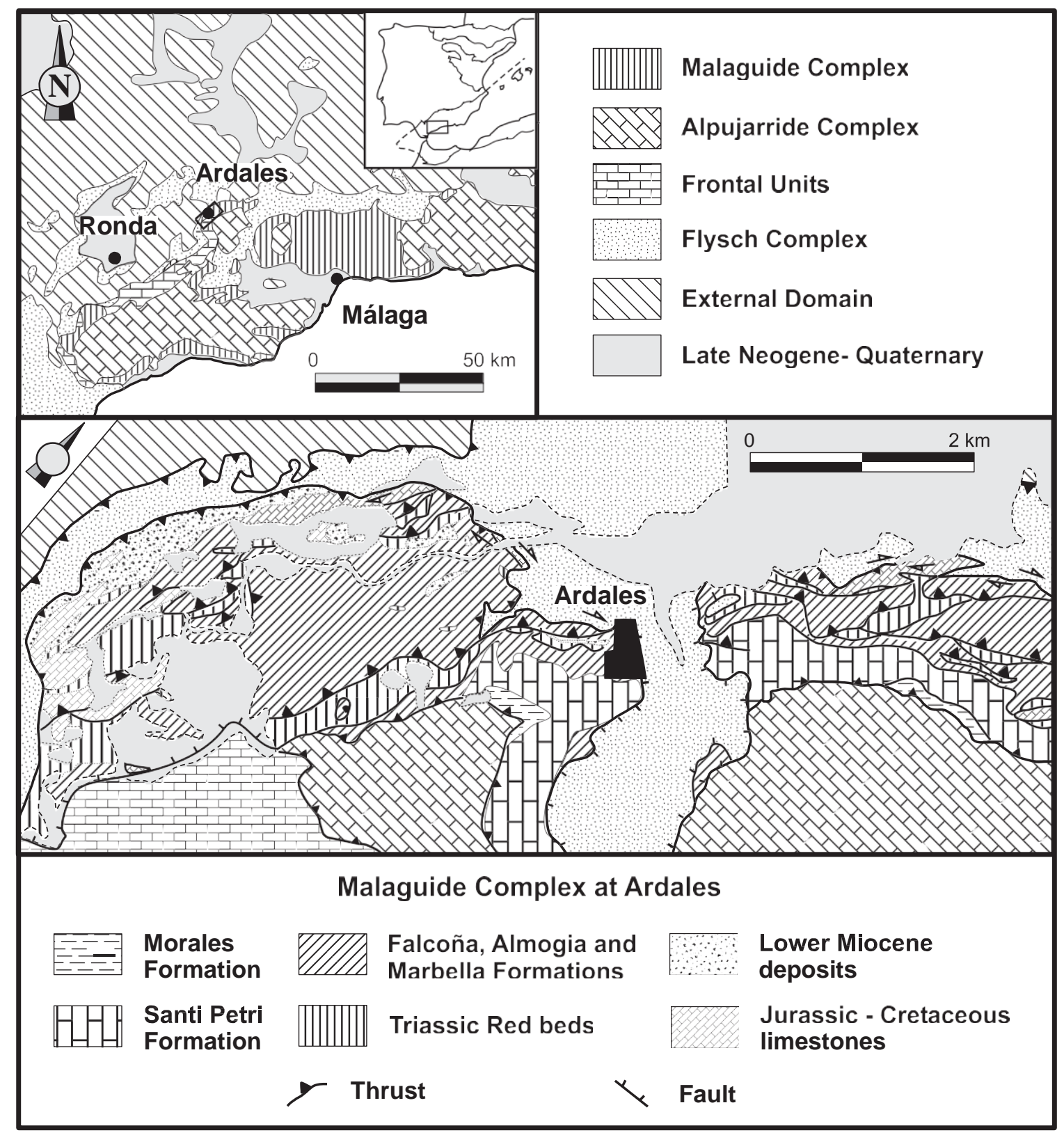

Fig. 1 Tectonic sketch of the Western Betic Cordillera and simplified geological map of the Malaguide Complex at Ardales.

Domains, as well as in the Frontal Units of the Internal Domain. They are, however, widely present in the other three tectonic complexes distinguished within the Internal Domain, which are named, from bottom to top, the Nevado-Filabride, Alpujarride and Malaguide complexes respectively. The Nevado-Filabride and Alpujarride Palaeozoic terranes consist exclusively of metamorphic rocks; pre-Mesozoic fossils have rarely been found there (Lafuste and Pavillon, 1976; Gómez-Pugnaire et al., 1982).
However, the Malaguide Palaeozoic terrain consists of thick, mainly siliciclastic and deep marine (turbiditic) successions bearing fossils (Marti' n- Algarra et al., 2004, and references therein).

The Malaguide Complex is exposed widely at Ardales, $30 \mathrm{~km}$ to the NE of Má laga, where it forms a narrow, discontinuous and strongly tectonized klippen belt (Fig. 1). The Malaguide succession cropping out there (Fig. 2) consists of Ordovician to Upper Car- boniferous rocks that were strongly deformed during pre-Alpine and Alpine events (Martín-Algarra et al., 2009a). Palaeozoic rocks include turbidites and slates, with subordinate conglomerate, chert and pelagic lime- stone bearing conodonts, and make up part of two superimposed Variscan tectonic units with different Palaeozoic successions, assigned to the Ermita (lower) and Peña del Castillo (upper) units (Martín-Algarra et al., 2009b).

From bottom to top, the studied succession in the Ermita Unit consists of (Figs 2 and 3): (a) a few metres of 


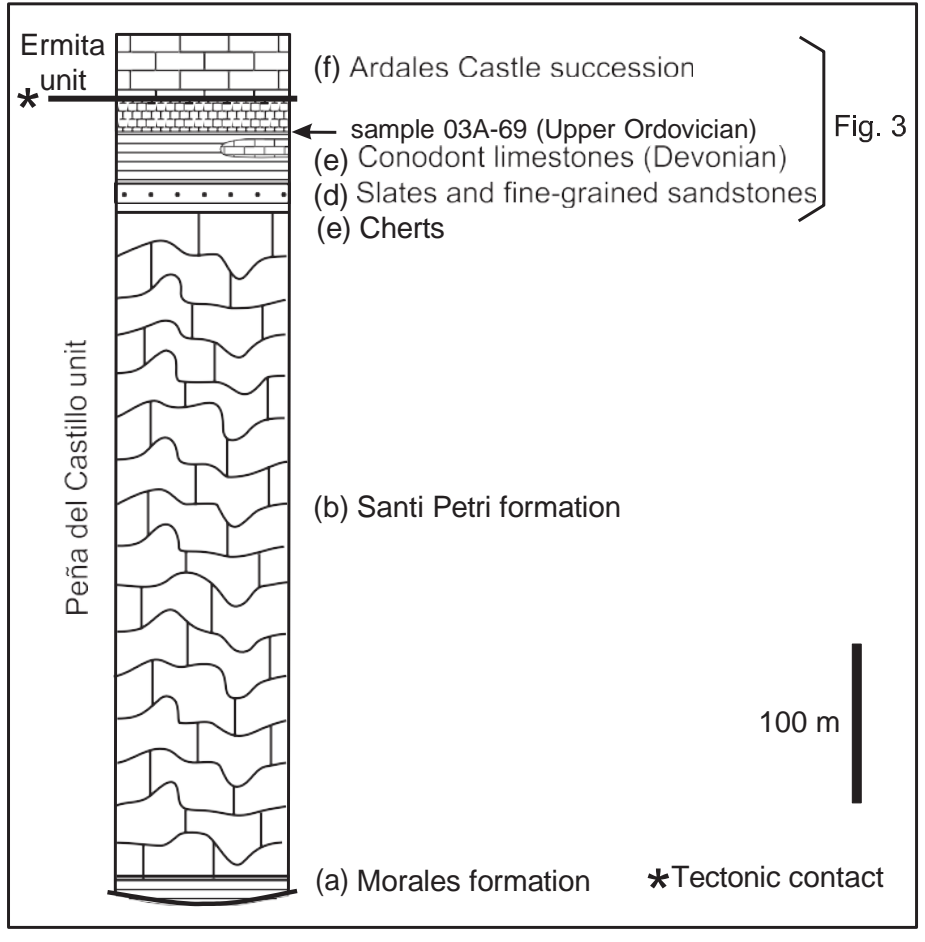

Fig. 2 Stratigraphy of the Malaguide Palaeozoic succession at Ardales.

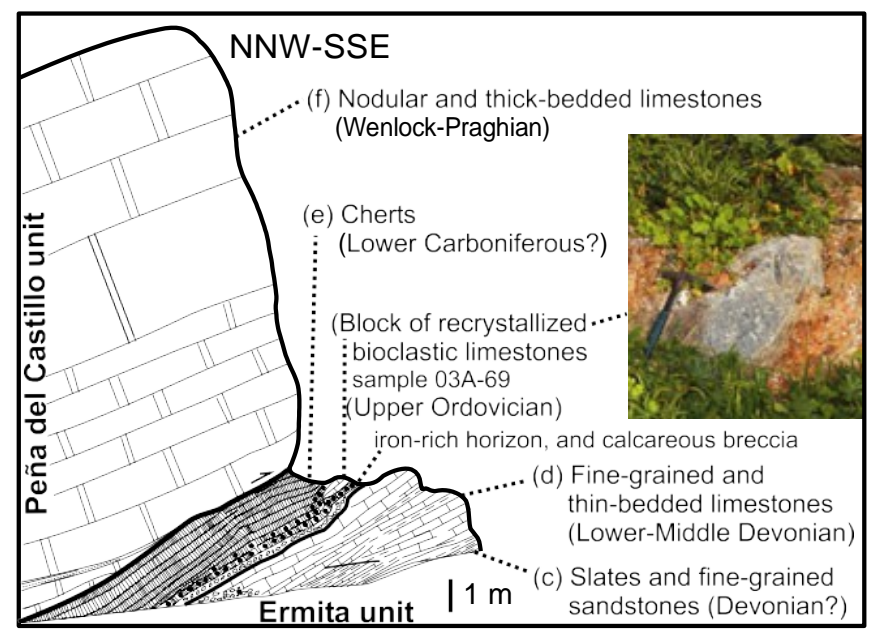

Fig. 3 The Ardales Castle Rock section and the location of the limestone conodont sample.

slightly metamorphic pre-Devonian slate and metasandstone belonging to the Morales Formation; (b) a thick and strongly folded succession of Devonian (?) calcareous slate and fine-grained turbiditic limestone of the Santi-Petri Formation; (c) a few tens of metres of slate and fine-grained sandstone with some discontinuous bodies of basic volcanic rock; (d) a few-metre-thick lens of grey-bluish fine-grained and thinly bedded pelagic limestone, with Lower to Middle Devonian conodonts and dacryoconarids (Rodríguez-Cañero, 1993a), which is bound by a thin brecciated horizon; and (e) a few metres of strongly sheared black radiolarian cherts, which are locally associated with bluish limestone bearing Lower Carboniferous (Visean) conodonts. This chert and limestone belonging to the Falcoña Formation is truncated by a preAlpine thrust fault that
Table 2 Late Ordovician conodont taxa from Ardales.

\begin{tabular}{|c|c|}
\hline The Ardales castle rock sec & \\
\hline Sample number & $03 A-69$ \\
\hline Amount of dissolved sample & $1975 \mathrm{~g}$ \\
\hline Amorphognathuscf. ordovicic & \\
\hline Pa element & 6 frag. \\
\hline $\mathrm{Pb}$ element & 3 \\
\hline Scabbardela altipes & \\
\hline a element & 9 \\
\hline$b$ ? element & 7 \\
\hline e element & 10 \\
\hline Scabbardellasp. & 5 \\
\hline Walliserodus amplissimus & \\
\hline a element & 3 \\
\hline b element & 2 \\
\hline c element & 2 \\
\hline $\mathrm{d}$ element & 2 \\
\hline e element & 9 \\
\hline Fragments & 18 \\
\hline Walliserodus cf. amplissimus & \\
\hline$d$ ? element & 4 \\
\hline e element & 1 \\
\hline Fragments & \\
\hline Walliserodus? sp. & 7 \\
\hline Protopanderodus? sp. & 1 \\
\hline Hamarodus europaeus & \\
\hline Scelement & 1 \\
\hline Eocarniodus & 2 \\
\hline Gen et sp. indet. & 9 \\
\hline Fragmentary specimens & 38 \\
\hline Total & 146 \\
\hline
\end{tabular}

divides the top of the lower (Ermita) Variscan tectonic unit from the base of the upper (Penña del Castillo) Variscan unit.

The Peñ a del Castillo Unit (Figs 2 and 3) is composed of SilurianLower Devonian nodular and thickly bedded limestone with conodonts (f), consti- tuting the approximately 30m-thick Ardales Castle succession (Rodríguez-Cañero,1993a; RodríguezCañero et al., 1997).

\section{Results and discussion}

The Ordovician conodont association was found in a block of recrystallized bioclastic limestone that lies within a siliceous-ferruginous-calcareous claystone horizon ( $<1 \mathrm{~m}$ thick) with discontinuous calcareous breccia, in the basal chert beds on top of the Middle Devonian pelagic limestone (levels e and d, above mentioned, respectively). The inclusion of the Ordovician block within surrounding sediments was probably the result of submarine sliding and resedimenta- 
tion (see discussion in Marti' nAlgarra et al., 2009a; p. 256). The sampled limestone block has a volume of about $0.3 \mathrm{~m}^{3}$ (Fig. 3).

In total, 146 conodont elements were recovered; the recognized taxa are summarized in Table 2. Specimen abundance is moderately high, with 75 elements per $\mathrm{kg}$ of dissolved sample. Conodont element size ranges from 0.2 to $1 \mathrm{~mm}$, thus indicating that hydrodynamic sorting was minimal. The specimens are well preserved in general: only a few are fragmentary; the colour alteration index of Epstein et al. (1977) is 4-4.5.

The low-diversity conodont fauna from Ardales includes Walliserodus Serpagli, 1967; Scabbardella Orchard, 1980; Amorphognathus Branson and Mehl, 1933; Hamarodus Viira, 1974 and Protopanderodus? Lindströ m, 1971 (Figs 4 and 5). Coniform ele- ments comprise more than $80 \%$ of the conodont collection; Walliserodus, including forms closely related to Silurian species, dominates the fauna (Figs 4 and 5). The genera Sagitto- dontina Knü pfer, 1967 and Istorinus Knü pfer, 1967 are, however, absent, although they are typical genera of the Mediterranean Province and indicative of the polar to subpolar regions of higher latitudes around Northern Gondwana (Sweet and Bergströ $m, 1984)$. Consequently, the Late Ordo- vician fauna found at Ardales cannot be ascribed to any of the Ordovician palaeobiogeographic provinces de- fined by Bergströ m (1973, 1990) and Sweet and Bergströ m (1984), neither can it be ascribed to any of the biofacies proposed by Sweet and Bergströ m (1984).

The conodont association of the Malaguide Complex at Ardales is very peculiar and differs significantly in taxonomic composition from associations in other areas of the Variscan
Orogen of the Iberian Peninsula dated as Katian, where Sagittodontina Knü pfer, 1967 and Istorinus Knü pfer, 1967 are common (Fuganti and Serpagli, 1968 Carls, 1975; Hafenrich-

ter, 1979; Sarmiento, 1990, 1993; Sarmiento et al., 1995, 1999, 2001, 2008; Sarmiento and Gutié rrezMar- co, 1999; Del Moral, 2003, 2005, 2007;

Del Moral and Sarmiento, 2008). These Katian conodonts have been recorded from several lithostratigraphic units belonging to different structural and palaeogeographic zones of the Variscan Iberian Massif (Table 3, Fig. 6): (i) the Cantabrian Zone (an unnamed formation at Portilla de Luna: Del Moral, 2003); (ii) the West Asturian Leonese Zone (La Aquiana Fm.: Sarmiento, 1993); (iii) the Iberian Cordillera (Cystoid Limestone and Ojos Negros formations: Carls, 1975; Hafenrichter, 1979; Del Moral, 2007); (iv) the Pyrenees (El Baell Fm.: Sanz-Ló pez and Sarmiento, 1995; and references therein); (v) the Catalonian Coastal Ranges (Madremanya Lime- stone: Sarmiento et al., 1995); (vi) the Central Iberian Zone (Casaio Fm., limestone pebbles of the Rozadais Fm., Urbana Limestone, Ferradosa Fm., and Adamuz Variscan olistoliths: Fuganti and Serpagli, 1968; Hafenrichter, 1979; Sarmiento, 1990, 1993; Sarmiento and Gutié rrezMar- co, 1999; Sarmiento et al., 2001; Del Moral, 2007; Del Moral and Sarmi- ento, 2008); and (vii) the Ossa-Mor- ena Zone (Pelmatozoan Limestone: Hafenrichter, 1979; Sarmiento et al., 2008).

The Ardales conodont fauna also differs from those of many other Southern European and North African sites: Thuringia (Knü pfer, 1967; Fer- retti and Barnes, 1997), NW France (Lindströ m and Pelhate, 1971; Weyant et al., 1977), Sardinia (Ferretti and Serpagli, 1999) and Libya (Bergströ m and Massa, 1992), where Sagittodontina and Istorinus are common but Walliserodus is scarce or absent.

Nevertheless, Late Ordovician conodont faunas from the Carnic Alps (Schö nlaub, 1988; Bagnoli et al., 1998; Ferretti and Schönlaub, 2001), North- ern England and North Wales (Orch- ard, 1980), and the Spanish Pyrenees (Sanz-López and Sarmiento, 1995) are similar to the Ardales fauna. Bagnoli et al. (1998) reported a more diverse conodont fauna without Sagittodonti- na and Istorinus from the Uggwa Formation of the Valbertad section (Carnic Alps). Ferretti and Schö nlaub (2001) also noticed the absence of Sagittodontina and Istorinus and sta- ted that (p. 9) Walliserodus amplissi- mus becomes dominant in the uppermost horizons of the Uggwa and Wolayer limestones of the Central Carnic Alps (Austria) and that (p. 10) Important levels with Hirnantia fauna were reported at the top of the Uggwa Limestone, immediately before the beginning of the Plöcken Unit. Orchard (1980) showed that A. ordovicicus?, W. aff. amplissimus and Hamarodus europaeus are the only conodonts present in Hirnantian levels of the Ashgill Series of Northern England and North Wales. Finally, in the associations from the Spanish Pyrenees, Sagittodontina and Istorinus are absent but Walliserodus is relatively abundant (Sanz-Ló pez and Sarmien- to, 1995) (Table 3).

As previously indicated, the Ardales fauna contains Walliserodus elements with a morphology similar to that of Silurian species (Figs 4 and 5). This suggests a replacement of Ordovician taxa by Silurian-like faunas in the latest Ashgill, as proposed by Barnes and Bergströ m (1988).

The Ardales conodonts correspond to generalist and eurythermal species from the Atlantic Faunal Region, as

\footnotetext{
Fig. 4 Late Ordovician conodonts of the Malaguide Complex at Ardales 1. Walliserodus amplissimus (Serpagli, 1967), a element; 03A-69-58. (a) Inner lateral view; (b) outer lateral view. 2. Walliserodus amplissimus (Serpagli, 1967, b element; 03A-69-60.

(a) Inner lateral view; (b) outer lateral view. 3. Walliserodus amplissimus (Serpagli, 1967), c element; 03A-69-50. (a) Inner lateral view; (b) outer lateral view. 4. Walliserodus amplissimus (Serpagli, 1967), d element; 03A-69-40. (a) Outer lateral view; (b) inner lateral view. 5. Walliserodus amplissimus (Serpagli, 1967), e element; 03A-69-57. (a) Inner lateral view; (b) outer lateral view. 6. Walliserodus amplissimus (Serpagli, 1967), e element; 03A-69-5. (a) Inner lateral view; (b) outer lateral view. 7. Walliserodus cf. amplissimus (Serpagli, 1967), a element; 03A-69-29. (a) Outer lateral view; (b) inner lateral view. 8. Walliserodus cf. amplissimus (Serpagli, 1967), b element; 03A-69-39. (a) Inner lateral view; (b) outer lateral view. 9. Walliserodus cf. amplissimus (Serpagli, 1967), a element; 03A-69-26. (a) Inner lateral view; (b) outer lateral view. 10. Walliserodus cf. amplissimus (Serpagli, 1967), a element; 03A-69-17. (a) Inner lateral view; (b) outer lateral view. 11. Walliserodus cf. amplissimus (Serpagli, 1967), b element; 03A-69-59. (a) Inner lateral view; (b) outer lateral view. 12. Walliserodus cf. amplissimus (Serpagli, 1967), e element; 03A-69-2. (a) Outer lateral view; (b) inner lateral view. White drawings correspond to the basal sections. Scale bars = 200 $1 \mathrm{~m}$.
} 


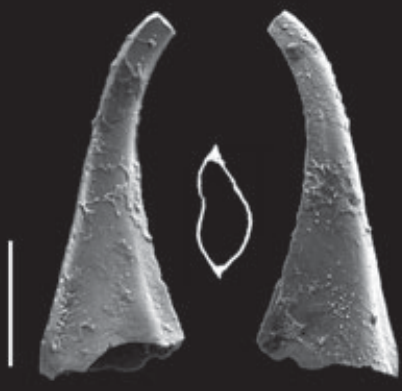

(1a)

(1b)

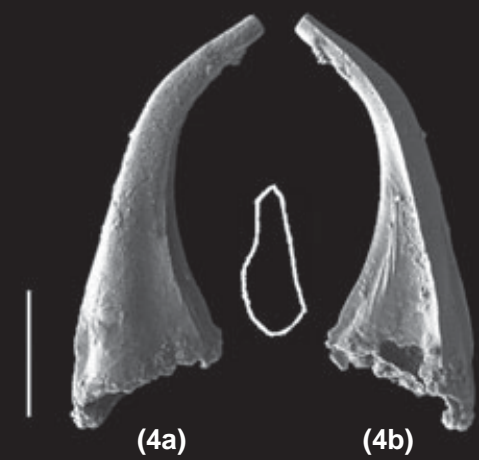

(4a)

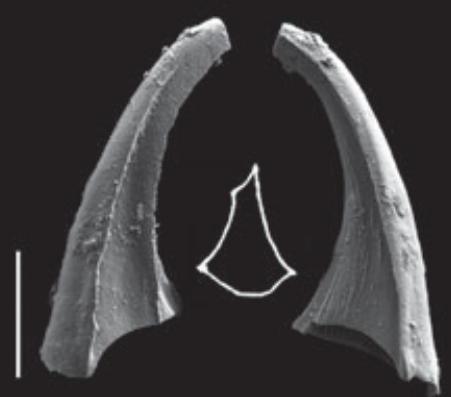

(2a)

(2b)

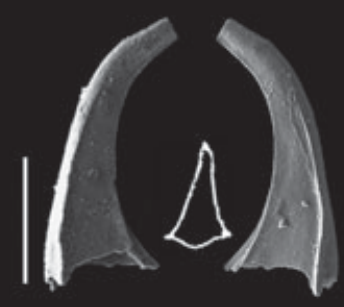

(3a)

(3b)
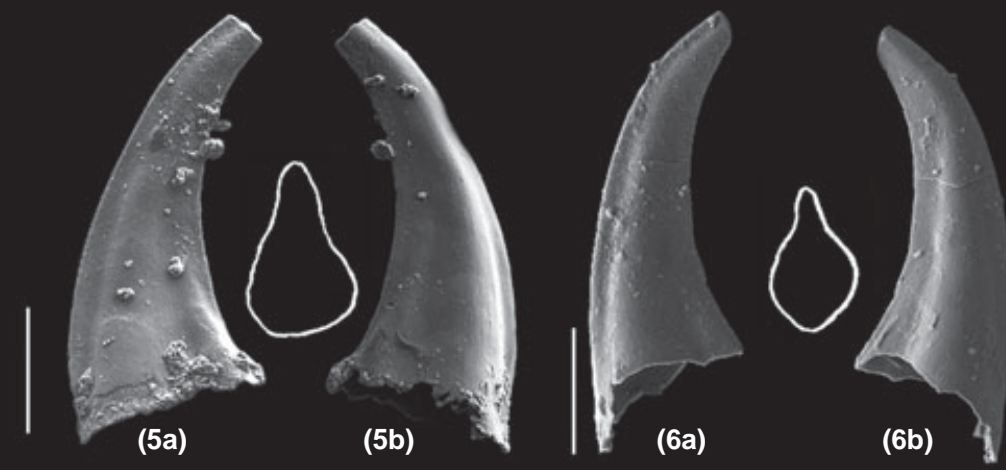

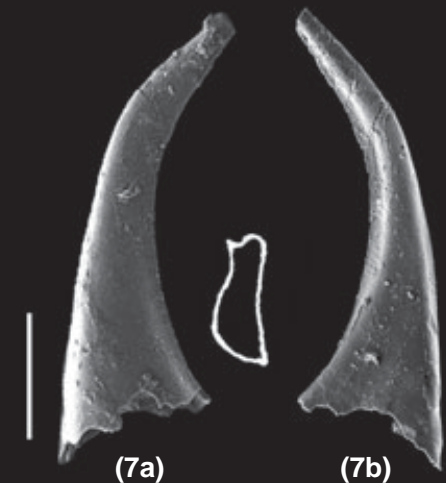

(7a)

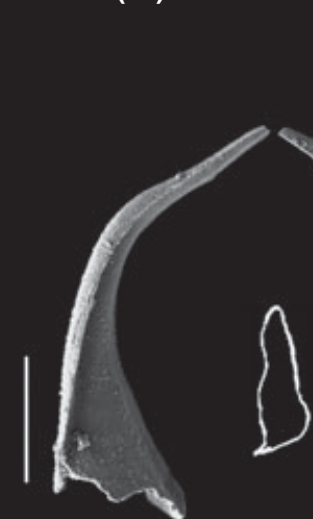

(10a)

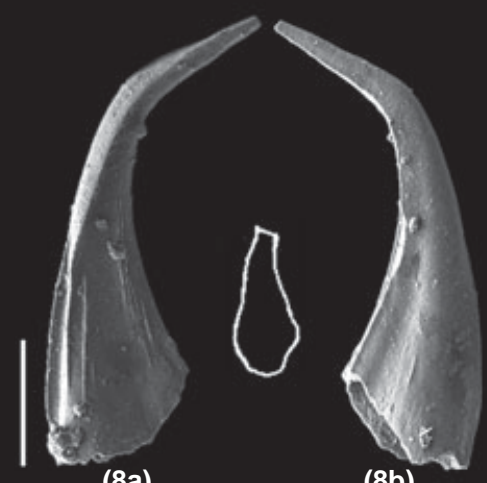

(8a)

(8b)

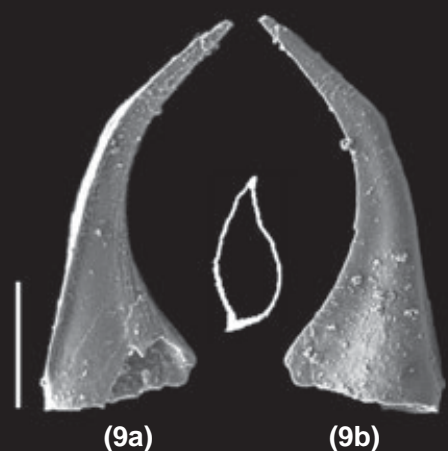

(9a)

(9b)

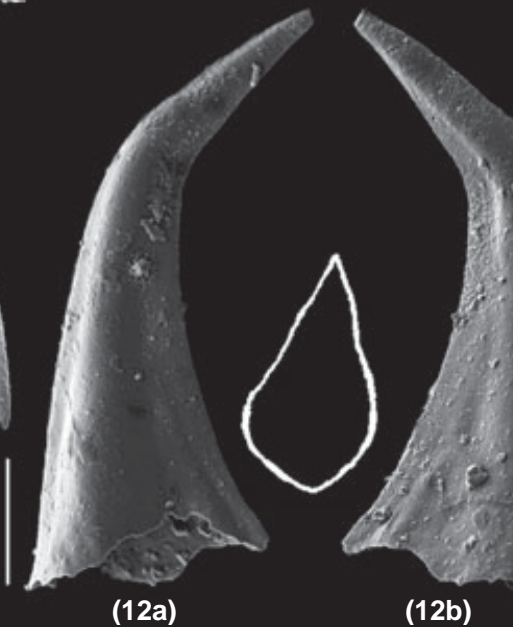

(12a)

(12b) 


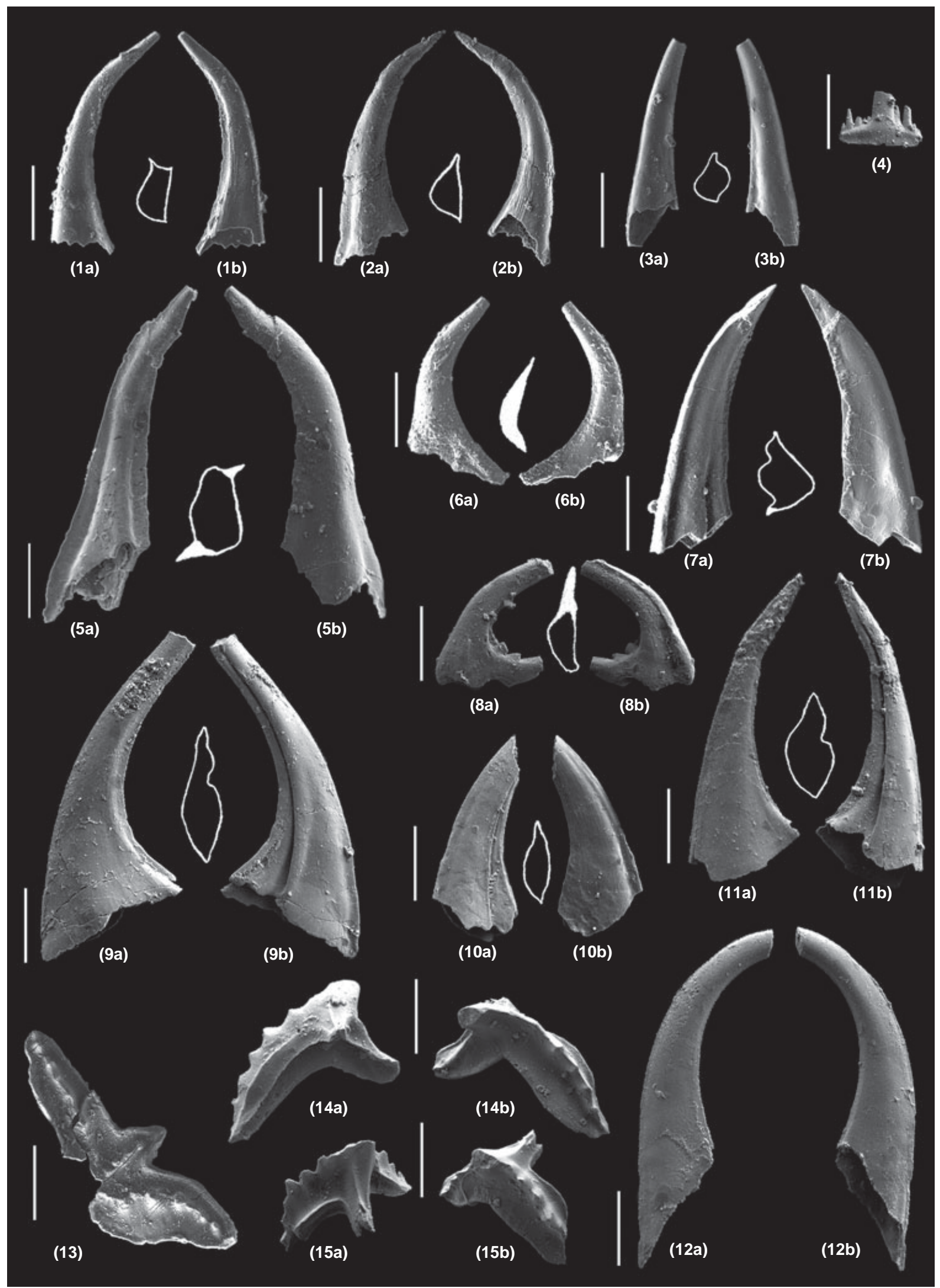


indicated by their low diversity and by the predominance of coniform taxa (Bergström, 1990). This suggests that the Malaguide fauna evolved under ecologically stressed conditions, and that only species adapted to rapidly changing environments survived. Hir- nantian conodont associations from the Atlantic Faunal Region are, in general, very scarce and poorly diversified (Orchard, 1980; Bergströ m and Orchard, 1985; Barnes and Williams, 1988). Moreover, they are absent from Hirnantian strata in other Spanish sites (Iberian Massif), where the sed-iments are dominated by glaciomarine diamictites (Carls, 1975; Robardet, 1981; Fortuin, 1984; and Robardet and Doré , 1988, among others).

Fig. 5 Late Ordovician conodonts of the Malaguide Complex at Ardales 1. Walliserodus? sp., 03A-69-7. (a) Outer lateral view; (b) inner lateral view. 2. Walliserodus? sp., 03A-69-8. (a) Outer lateral view; (b) inner lateral view. 3. Walliserodus? sp., 03A-69-12. (a) Outer lateral view; (b) inner lateral view. 4. Eocarniodus element, 03A-69-104. 5. Gen et sp. indet., 03A-69-61. (a) Inner lateral view; (b) outer lateral view. 6. Protopanderodus? sp., 03A-69-16. (a) Outer lateral view; (b) inner lateral view. 7. Gen et sp. indet., 03A-69-36. (a) Inner lateral view; (b) outer lateral view. 8. Hamarodus europaeus (Serpagli, 1967), Sc element; 03A-69-106. (a) Inner lateral view; (b) outer lateral view. 9. Scabbardella altipes (Henningsmoen, 1948), a element; 03A69-74. (a) Outer lateral view; (b) inner lateral view. 10. Scabbardella altipes (Henningsmoen, 1948), b? element; 03A69-79. (a) Inner lateral view; (b) outer lateral view. 11. Scabbardella alt-ipes (Henningsmoen, 1948), a element; 03A69-74. (a) Outer lateral view; (b) inner lateral view. 12. Scabbardella alt- ipes (Henningsmoen, 1948), e element; 03A69-64. (a) Outer lateral view; (b) inner lateral view. 13. Amorphognathus cf. ordovicicus Branson and Mehl, 1933, Pa element; 03A-69-67, upper view. 14. Amorphognathus cf. ordovicicus Branson and Mehl, 1933, Pb element; 03A-69-72. (a) Outer oblique view; (b) upper view. 15. Amorphognathus cf. ordovicicus Branson and Mehl, 1933, Pb element; 03A-69-71. (a) Outer lateral view; (b) upper view. White drawings correspond to the basal sections. Scale bars $=200 \mathrm{~lm}$.

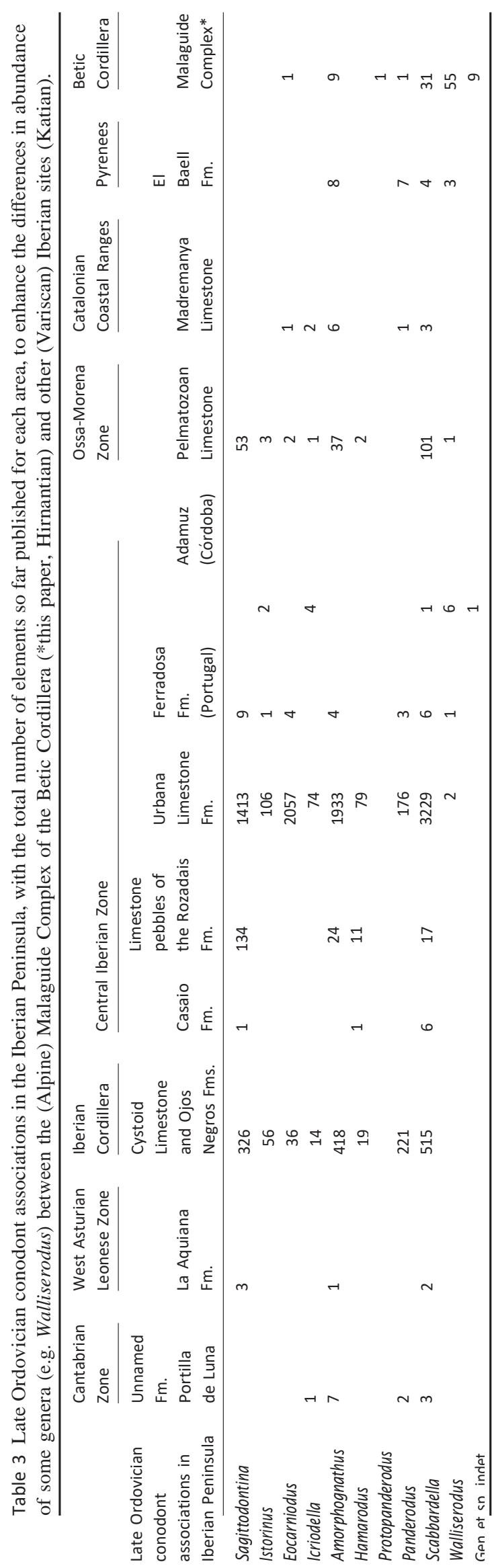



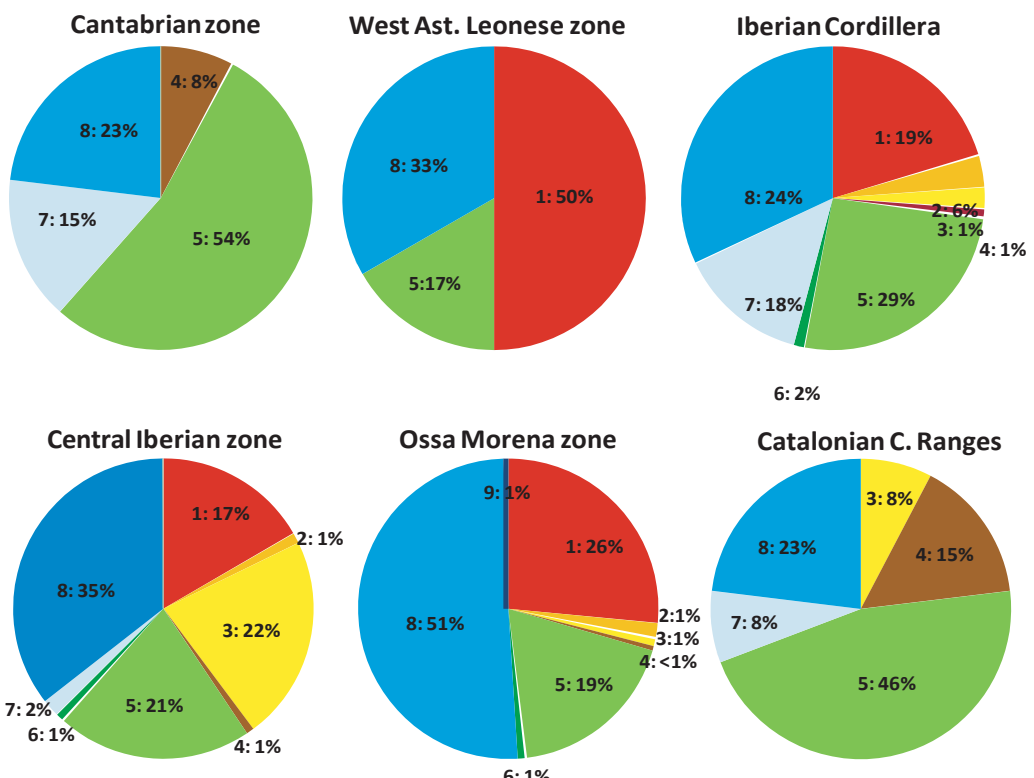

$6: 2 \%$
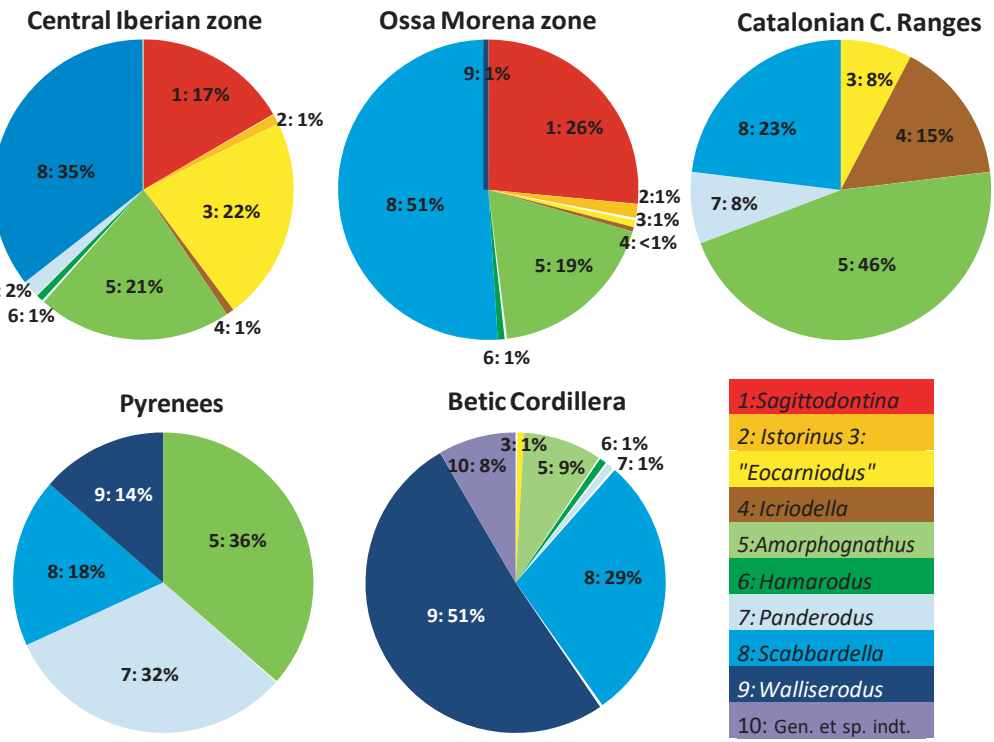

Fig. 6 Taxonomic compositions of Late Ordovician conodont taxa from different tectonostratigraphic zones of the Iberian Peninsula.

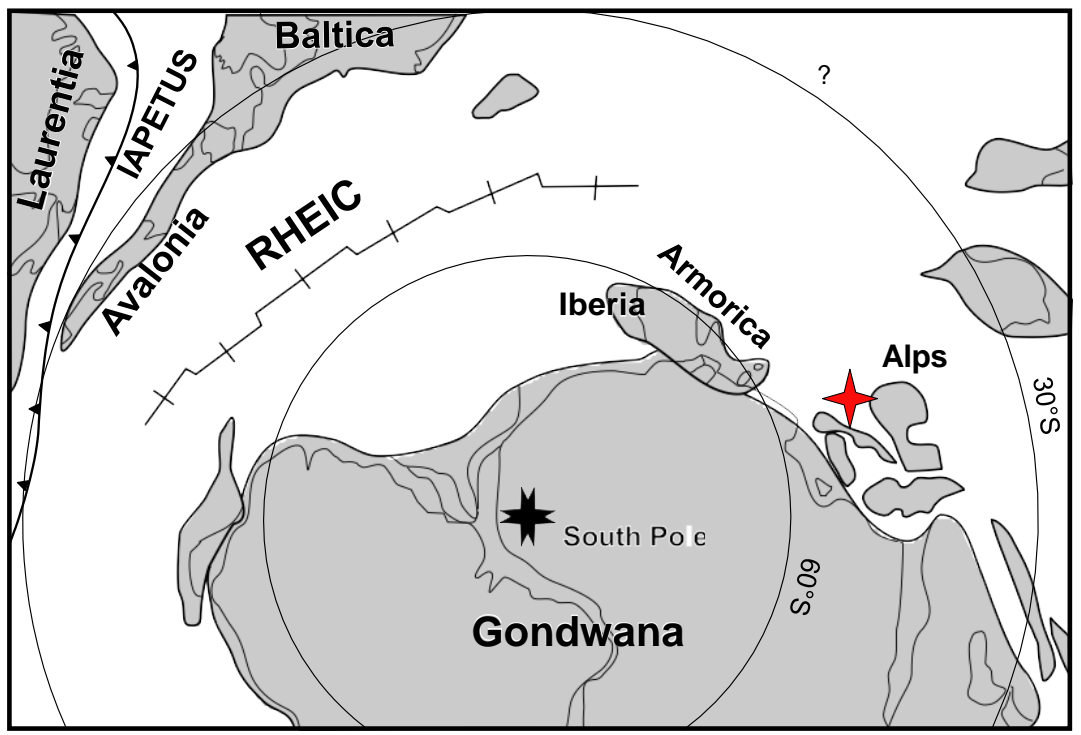

Fig. 7 Palaeogeographic reconstruction of North Gondwana during the Upper Ordovician (simplified from Cocks and Torsvik, 2006). The star indicates the proposed location of the Malaguide Complex of the Betic Cordillera 440 Ma ago.
Lindström (1976), Sweet and Bergström (1984) and Bergström (1990) located the Iberian Peninsula at very high palaeolatitude, as part of the Perigondwanic margin, during the latest Ordovician. This would explain quite well the absence of conodonts and the predominance of glaciomarine sediments during the Hirnantian in most Iberian areas. Nevertheless, the affinities between the Ardales Ordovician fauna and the conodont associations found in the Carnic Alps rather suggest a palaeogeographical location for the Malaguide Complex at lower palaeolatitude than the Iberian Massif, as proposed by Cocks and Torsvik (2002, 2006) for the Carnic Alps, or by Vennin et al. (1998) for the northeastern regions of Iberia. This palaeobiogeographical interpretation is geologically significant and reinforces a previous hypothesis supporting close palaeogeographical relationships between the Palaeozoic (and younger) successions of the Betic-Rifian Internal Domains and those of the Alps (see Chalouan and Michard, 1990; Michard et al., 1991, among others).

\section{Conclusions}

1 The presence of Upper Ordovician rocks in the Malaguide Complex is demonstrated for the first time.

2 The Late Ordovician conodont fauna discovered at Ardales is correlated with the upper part of the A. ordovicicus Biozone, corresponding to the Hirnantian Stage. This is supported by: (i) its dissimilarity from typical Katian associations of the Mediterranean Province reported in other areas of the Iberian Massif; (ii) its similarity to associations recorded from the upper levels of the Uggwa limestones of the Carnic Alps and to the Hirnantian fauna of the Ashgill Series of Northern England and North Wales; and (iii) the presence of Walliserodus elements showing morphological affinities to Early Silurian species.

3 The conodont association found at Ardales indicates deposition at a lower palaeolatitude than that of other Iberian regions. It is similar to conodont faunas from the Carnic Alps, thus suggesting that close palaeogeographical relationships 
exist between the Malaguide Complex and the Alps.

4 Accordingly, during the Late Ordovician, the Malaguide Complex was located at an intermediate palaeogeographic position between the Carnic Alps and the Iberian terranes (Fig. 7).

\section{Acknowledgements}

This paper is a contribution to the IGCP project 503, and was supported by the Project CGL2009-09249, MEC, Spain and RNM groups 208 and 3715 (Junta de Andaluci' a). Our sincere thanks are due to

J. C. Gutiérrez-Marco (CSIC-UCM) for his valuable comments on the earlier version of the manuscript. Thanks are also extended to Stan Finney (CSULB) for language correction, and three anonymous referees for their useful suggestions.

\section{References}

Bagnoli, G., Ferretti, A., Serpagli, E. and Vai, J.B., 1998. Late Ordovician conodonts from the Valbertad Section (Carnic Alps). Seventh International conodont Symposium held in Europe. Giorn. Geol., 60, 138-149. Special Issue. ECOS VII Southern Alps Field Trip Guidebook.

Barnes, C.R. and Bergström, S.M., 1988. Conodont biostratigraphy of the Uppermost Ordovician and Lowermost Silurian. In: A Global Analysis of the Ordovician-Silurian Boundary (L.R.M. Cocks and R.B. Richards, eds). Bull. Br. Mus. Nat. Hist., 43, 325-343.

Barnes, C.R. and Williams, S.H., 1988. Conodont from the Ordovician-Silurian boundary stratotype, Dob's Linn, Scotland. In: A Global Analysis of the Ordovician-Silurian Boundary (L.R.M. Cocks and R.B. Richards, eds). Bull. Br. Mus. Nat. Hist., 43, 31-39.

Bergström, S.M., 1973. Ordovician conodonts. In: Atlas of Palaeobiogeography (A. Hallam, ed.), pp. 47-58. Elsevier Scientific Publishing Company, Amsterdam.

Bergström, S.M., 1990. Relations between provincialism and the changing paleogeography during the Early Paleozoic. In: Palaeozoic, Palaeogeography and Biogeography (W.S. McKerrow and C.R. Scotese, eds). Geol. Soc. Mem., 12, 105-121.

Bergströ m, S.M. and Massa, D., 1992. Stratigraphic and biogeographic significance of Upper Ordovician conodonts from northwestern Libya. In: The Geology of Libya (M.J. Salem, O.S. Hammuda and B.A. Eliagoubi, eds), pp. 1323-1342. Elsevier, Amsterdam.

Bergströ m, S.M. and Orchard, M.J., 1985.Conodonts of the Cambrian and
Ordovician System from the British Isles. In: A Stratigraphical Index of Conodonts (A.C. Higgins and R.L. Austin, eds), pp. 32-67. Ellis Horwood Ltd, Chichester.

Bergströ m, S.M., Chen, X., Gutié rrezMarco, J.C. and Dronov, A., 2009. The new chronostratigraphic classification of the Ordovician System and its relations to major regional series and stages and to $\mathrm{d}^{13} \mathrm{C}$ chemostratigraphy. Lethaia, 42 , 97-107.

van den Boogaard, M., 1965. Two conodont fauna from the Paleozoic of the Betic of Má laga near Vé lez Rubio S.E. Spain. Verh. Kon. Ned. Akad. v. Wet. Series B, 68, 33-37.

Branson, E.B. and Mehl, M.G., 1933. Conodont studies, numbers 1 and 2. Univ. Missouri Stud., VIII, 1-167.

Buchroithner, M., Flü gel, E., Flü gel, H.W. and Stattegger, K., 1980 Mikrofazies, Fossilien und Herkunft der Kalk-Gerö lle im Karbon-'Flysch' der Betischen Kordilleren, Spanien. Facies, $2,1-54$.

Carls, P., 1975. The Ordovician of Eastern Iberian Chains near Fombuena and Luesma (Prov. Zaragoza, Spain). N. Jb. Geol. Paläont. Abh., 150,127146.

Chalouan, A. and Michard, A., 1990. The Ghomarides Nappes, Rif Coastal Range, Morocco - A Variscan chip in the Alpine belt. Tectonics, 9, 1565-1583.

Cocks, L.R.M. and Torsvik, T.H., 2002. Earth geography from 500 to 400 million years ago: a faunal and palaeomagnetic review. J. Geol. Soc., 159, 631-644.

Cocks, L.R.M. and Torsvik, T.H., 2006. European geography in a global context from the Vendian to the end of the Palaeozoic. In: European Lithosphere Dynamics (D.G. Gee and R.A. Stephenson, eds). Geol. Soc. Mem., 32, 8395.

Del Moral, B., 2003. Primeros conodontos Kralodvorienses (Ordovi' cico superior) de la Zona Cantá brica, Portilla de Luna, Leó n (Españ a). Rev. Esp. Micropal., 35, 275-283.

Del Moral, B., 2005. Estudio tafonó mico preliminar de los conodontos de la Formació n Caliza de Cistoideos (Ordoví cico Superior) en la secció n Piedra del Tormo (Cordillera Ibé rica, Zaragoza, España). In: VIII Jornadas Aragonesas de Paleontología (J.A. Gámez Vintaned, E. Liñaan and J.I. Valenzuela Ríos, eds), pp. 109-118. Excelentísima Diputación de Zaragoza.

Del Moral, B., 2007. Conodontos y Microfacies del Ordovícico Superior de la Cordillera Ibérica y Sierra Morena Oriental. Unpublished $\mathrm{PhD}$ thesis, Universidad Complutense de Madrid, Spain, $427 \mathrm{pp}$

Del Moral, B. and Sarmiento, G.N., 2008 Conodontos del Katiense (Ordovícico Superior) del sector meridional de la
Zona Centroibérica (España). Rev. Esp. Micropal., 40, 169-245.

Durand-Delga, M. and Fontboté, J.M., 1980. Le cadre structural de la Mé diterrané e occidentale. Mem. B. R. G. M., 115, 67-85.

Epstein, A.G., Epstein, J.B. and Harris, L.D., 1977. Conodont color alteration an index to organic metamorphism. Geol. Surv. Prof. Pap., 995, 1-27.

Ferretti, A. and Barnes, C., 1997. Upper Ordovician Conodonts from the Kalbank Limestone of Thuringia, Germany. Paleontology, 40, 15-42.

Ferretti, A. and Schö nlaub, H.P., 2001. New conodont faunas from the Late Ordovician of Central Carnic Alps, Austria. Boll. Soc. Paleont. It., 40, 3-15.

Ferretti, A. and Serpagli, E., 1999. Late Ordovician conodont faunas from southern Sardinia, Italy: biostratigraphic and paleogeographic implications. Boll. Soc. Paleont. It., 37, 215-236.

Fortuin, A.R., 1984. Late Ordovician glaciomarine deposits (Orea Shale) in the Sierra de Albarraci'n, Spain. Palageogr. Palaeoclimat. Palaeoecol., 48, 245-261.

Fuganti, A. and Serpagli, E., 1968. Geological remarks on Urbana Limestone and evidence for its Upper Ordovician age by means of conodonts - Eastern Sierra Morena, South Spain. Boll. Soc. Paleont. It., 87, 511-521.

Gó mez-Pugnaire, M.T., Chacó n, J., Mitrofanov, F. and Timofeiev, B., 1982 First report on Precambriam rocks in the Graphite bearing Series of the NevadoFilá bride Complex (Betic Cordillera). N. Jb. Geol. Paläont. Mh., 3, 176-180.

Hafenrichter, M., 1979. Palä ontologisch- ökologische und lithofazielle unters- unchungen des 'Ashgill-kalkes' (Jung- ordovizium) in Spanien. Arb. Paläont. Inst. Wu'rburg, 3, 139 .

Henningsmoen, G., 1948. The Tretaspis Series of the Kullatorp core. Bull. Geol. Inst.Univ. Upsala, 32, 374-432.

Herbig, H.G., 1983. El Carbonı' fero de las Cordilleras Bé ticas. In: Carbonifero y Pérmico de España (M. Díaz, ed.), pp. 343-356. X. Congr. Intern. Estrat. Geol. Carbonífero, Madrid.

Herbig, H.G., 1984. Rekonstruktion eines nicht mehr existenten SedimentationsRaums: die Kalk-Gerölle im Karbon Flysch der Malagiden (Betische Kordillere, Sư dspanien). Facies, 11, 1-108.

Herbig, H.G., 1985. An Upper Devonian limestone slide block near Marbella (Betic Cordillera, Southern Spain) and the palaeogeographic relations between Malaguides and Menorca. Acta Geol. Hispánica, 20, 155-178.

Knüpfer, J., 1967. Zur Fauna und Biostratigraphie des Ordoviziums (Grä fent- haler Schichten) in Thü ringen. Freib. Forsch., C220, 1-119. 
Kockel, F., 1959. Conodontos del Paleozoico de Málaga. Not. Com. IGME, 53, 149-164.

Kockel, F. and Stoppel, D., 1962. Nuevos hallazgos de conodontos y algunos cortes en el Paleozoico de Má laga (Sur de España). Not. Com. IGME, 65, 133170

Lafuste, J. and Pavillon, M.J., 1976. É vidence d'Eifé lien daté au series de terrains mé tamorphiques des Zones Internes des Cordillè res Bé tiques. Intérêt de ce nouveau repère stratigraphique. C. R. Acad. Sci Paris, Série D, 283, 1015-1018.

Lindström, M., 1971. Lower Ordovician conodonts of Europe. In: Symposium on Conodont Biostratigraphy (W.C. Sweet and S. Bergström, eds). Geol.Soc. Am. Mem., 127, 21-61.

Lindström, M., 1976. Conodont Palaeogeography of the Ordovician. In: The Ordovician System. Palaeontological Association Symposium Proceedings, Birmingham. (M.G. Basset, ed.), pp. 501-522. University of Wales Press and Nacional Museum of Wales, Cardiff.

Lindströ m, M. and Pelhate, A., 1971. Pré - sence de conodontes dans les calcaires de Rosan (Ordovicien moyen a supé rieur Massif Armoricain). Mém. B.R.G.M, 73, 89-91.

Martin-Algarra, A., 1987. Evolución Geológica Alpina del Contacto Entre las Zonas Internas y la Zonas Externas de la Cordillera Bética. PhD Thesis. Universidad de Granada, Spain. Dpto. Estratigrafía y Paleontología, eds. pp. 1171.

Martín-Algarra, A., Rodríguez-Cañero, R., O'Dogherty, L., Sánchez-Navas, A. and Ruiz-Cruz, M.D., 2004. Complejo Malá guide. Estratigrafía. Paleozoico ¿y más antiguo? (Grupo Piar). In: Geología de España (J.A. Vera, ed.), pp. 401-404. SGE-IGME, Madrid.

Martín-Algarra, A., Mazzoli, S., Perrone, V., Rodríguez-Cañero, R. and NavasParejo, P., 2009a. Variscan tectonics in the Malaguide Complex (Betic Cordillera, Southern Spain): stratigraphic and structural Alpine versus Pre-Alpine constraints from the Ardales Area (Province of Málaga). I. Stratigraphy. J. Geol., 117, 241-262.

Martín-Algarra, A., Mazzoli, S., Perrone, V. and Rodrí guez-Cañero, R., 2009b. Variscan tectonics in the Malaguide Complex (Betic Cordillera, Southern Spain): stratigraphic and structural $\mathrm{Al}-$ pine versus Pre-Alpine constraints from the Ardales Area (Province of Má laga). II. Structure. J. Geol., 117, 263284. Michard, A., Goffé , B., Chalouan, A. and Saddiqi, O., 1991. Les corré lations entre les Chaînes bé tico-rifaines et les Alpes et leurs consé quences. Bull. Soc. Géol.France, 162, 1151-1160.

Navas-Parejo, P., Rodríguez-Cañero, R. and Martín-Algarra, A., 2008.
Conodontos del Carbonífero Maláguide en Vélez Rubio (Cordillera Bé tica, SE Spain). Geo-Temas, 10, 1273-1276.

O'Dogherty, L., Rodríguez-Cañero, R., Gursky, H.J., Caridroit, M. and MartínAlgarra, A., 2000. New data on age and occurrence of the early Carboniferous radiolarians chert and associated limestones in the Malaguide Complex (Betic Cordillera, Southern Spain). C. R. Acad. Sci. Paris II a, 331, 533-541.

Orchard, M.J., 1980. Upper Ordovician conodonts from England and Wales. Geol. Palaeontol., 14, 9-44.

Robardet, M., 1981. Late Ordovician tillites in the Iberian Peninsula. In: Earth Pre-Pleistocene Glacial Record (M.J. Hambrey and W.B. Harland, eds), pp. 585-589. Cambridge University Press, Cambridge.

Robardet, M. and Doré, F., 1988. The late Ordovician diamictic formations from southwestern Europe: northGondwana glaciomarine deposits. Palaeogeogr. Palaeoclimat. Palaeoecol., 66, 19-31.

Rodríguez-Cañero, R., 1993a. Contribuciónal Estudio de los Conodontos del Paleozoico del Complejo Maláguide(Cordil lera Bética). Unpublished $\mathrm{PhD}$ thesis, Universidad de Málaga, Spain, 474 pp.

Rodríguez-Cañero, R., 1993b. Presencia del evento de extinció n Frasniense en el Complejo Maláguide (Cordillera Bética), detectado mediante fauna de conodontos. In: Comunicaciones de las IX Jornadas de Paleontología (J.M. Gonzá lez Donoso, ed.), pp. 13-17. Sociedad Españ ola de Paleontología, Málaga, Spain.

Rodríguez-Cañero, R. and Guerra-Merchá n, A., 1996. Nuevos datos sobre la fauna de conodontos y la edad de la Formacion Falcoña (Complejo Maláguide, Cordillera Bética). Rev. Esp. Paleont., 11, 235-246.

Rodríguez-Cañero, R., García-López, S. and Sarmiento, G.N., 1997. Conodontos siluro-devó nicos de la Peñ a de Ardales (Complejo Maláguide, Cordillera Bética). In: Comunicaciones de la XIII Jornadas de Paleontología (A Grandal D'Anglade, J.C. Gutié rrez Marco and

L. Santos Hidalgo, eds), pp. 92-94. Sociedad Española de

Paleontología, A Coruña, Spain.

Sanz-Ló pez, J. and Sarmiento, G.N., 1995. Asociaciones de conodontos del Ashgill y Llandovery en horizontes carbonatados del Valle del Freser (Girona). In: Co- municaciones XI Jornadas de Paleontología (G. López, A. Obrador and E. Vicens, eds), pp. 157160. Sociedad Española de Paleontología, Tremp, Spain.

Sarmiento, G.N., 1990. Conodontos de la Zona Ordovicicus (Ashgill) en la Caliza Urbana, Corral de Calatrava (Ciudad
Real). Geogaceta, 7, 54-56.

Sarmiento, G.N., 1993. Conodontos Ordovícicos de Sierra Morena Macizo Hespérico Meridional. Unpublished $\mathrm{PhD}$ thesis, Universidad Complutense de Madrid, Spain, 597 pp.

Sarmiento, G.N. and Gutié rrez-Marco, J.C., 1999. Microfósiles ordovícicos en olistolitos carboní feros de la Cuenca del Guadiato, Adamuz (Có rdoba). Temas Geologico-Mineros ITGE, 26, 580-584.

Sarmiento, G.N., Sanz López, J. and Barnolas, A., 1995. Conodontos del Ashgill en las Calizas de Madremanya, Les Gavarres (Girona). In: Comunicaciones XI Jornadas de Paleontología (G. Ló pez, A. Obrador and E. Vicens, eds), pp. 161-163. Sociedad Españ ola de Paleontología, Tremp, Spain.

Sarmiento, G.N., Gutiérrez-Marco, J.C. and Robardet, M., 1999. Conodontos ordoví cicos del Noroeste de Españ a. Aplicació $\mathrm{n}$ al modelo de sedimentacion de la región limí trofe entre las zonas AsturoccidentalLeonesa y Centroibérica durante el Ordovícico Superior.

Rev. Soc. Geol. Esp., 12, 477-500.

Sarmiento, G.N., Del Moral, B. and Piç arra, J.M., 2001. Conodontos del Ordovi' cico Superior (Ashgill) en la Serra do Buç aco. Col. Paleont., 52, 95105.

Sarmiento, G.N., Gutié rrez-Marco, J.C. and Del Moral, B., 2008. Conodontos de la 'Caliza de Pelmatozoos' (Ordovícico Superior), Norte de Sevilla, Zona de Ossa-Morena (España). Col. Paleont., 58, 73-99.

Schönlaub, H.P., 1988. The OrdovicianSilurian boundary in the Carnic Alps of Austria. Bull. Br. Mus. Nat. Hist. (Geol.), 43, 107-115.

Serpagli, E., 1967. I conodonti dell'Ordoviciano Superiore Ashgilliano delle Alpi Carniche. Boll. Soc. Paleont. Ital., 6, 30-111.

Sweet, W.C. and Bergström, S.M., 1984. Conodont provinces and biofacies of the Late Ordovician. Geol. Soc. Amer. Spec. Pap., 196, 69-87.

Vennin, E., Álvaro, J.J. and Villas, E., 1998. High-latitude pelmatozoanbryozoan mud-mounds from the late Ordovician northern Gondwana platform. Geol. J., 33, 121-140.

Vera, J.A. and Martín-Algarra, A., 2004. Divisiones mayores y nomenclatura. In: Geología de España, Cap. 4: Cordillera Bética y Baleares (J.A. Vera, ed.), pp. 348-350. SGE and IGME, Madrid.

Viira, V., 1974. Ordovician Conodonts of the Baltic Region. Valgus, Tallin, 142 pp. [In Russian].

Weyant, M., Doré., F., Le Gall, J. and Poncet, J., 1977. Un épisode calcaire ashgillien dans l'est du Massif armoricain, incidence sur l'age des depôts glacio- marins fini-ordoviciens. $C R$ Acad. Sci. Paris, 284, 1147-1149. 